\title{
FEM BURNISHING SIMULATION INCLUDING ROUGHNESS
}

\author{
SYMULACJA PROCESU NAGNIATANIA \\ METODĄ ELEMENTÓW SKOŃCZONYCH Z UWZGLĘDNIENIEM \\ CHROPOWATOŚCI POWIERZCHNI
}

\author{
Alberto SALDAÑA-ROBLES ${ }^{1}$, Eduardo AGUILERA-GÓMEZ ${ }^{1}$, \\ Héctor PLASCENCIA-MORA ${ }^{1}$, Elías R. LEDESMA-OROZCO ${ }^{1}$, \\ Juan F. REVELES-ARREDONDO ${ }^{1}$, Noé SALDAÑA-ROBLES ${ }^{2}$
}

\begin{abstract}
Ball burnishing is a surface improvement process that provides compressive residual stresses and increment the hardness in the surface layer of workpieces. Actually, in the state of the art some papers use FEM to simulate the burnishing process in the most cases without consideration the roughness of the workpiece, in other cases the roughness is considered only as two-dimensional semicircular or triangular periodic pattern. In other studies to simulate three-dimensional roughness, the two dimensional case is extruded. In this paper, a new way to simulate three-dimensional random roughness was used to simulate the ball burnishing process obtaining the final roughness and residual stresses distribution in the surface and below it. For the simulation, a commercial explicit FEA Software was used considering a bilinear material model. The finite element model of ball burnishing process was validated with experimental test and the methodology of this simulation process is presented.
\end{abstract}

Keywords: burnishing, surface roughness, FEM simulation

Streszczenie: Nagniatanie jest procesem stosowanym w celu poprawy powierzchni, który zapewnia ściskające naprężenia szczątkowe i wzrost twardości w warstwie wierzchniej przedmiotów obrabianych. Według aktualnego stanu wiedzy w kilku przypadkach do symulacji procesu nagniatania używano MES, jednakże w większości przypadków nie uwzględniono chropowatości powierzchni przedmiotu obrabianego, a w innych chropowatość była traktowana jako dwuwymiarowy powtarzalny kształt półokrągły lub trójkątny. W innych badaniach, do symulacji chropowatości trójwymiarowej użyto modelu powstałego przez wyciągnięcie przypadku dwuwymiarowego. W niniejszej pracy użyto nowego sposobu

\footnotetext{
${ }^{1}$ Universidad de Guanajuato, DICIS, Department of Mechanical Engineering, 36885, Palo Blanco, Salamanca, Guanajuato, México

${ }^{2}$ Universidad de Guanajuato, DICIVA, Department of Agricultural Engineering, 36820, Ex Hacienda El Copal, Irapuato, Guanajuato, México
} 
symulacji stochastycznej chropowatości 3D do symulacji procesu nagniatania uzyskując końcową chropowatość powierzchni i końcowy rozkład naprężeń szczątkowych na powierzchni i pod nią. Do symulacji użyto komercyjnego oprogramowania MES z jawnym całkowaniem równań ruchu $\mathrm{z}$ uwzględnieniem dwuliniowego modelu materiału. Model procesu nagniatania otrzymany metodą elementów skończonych został potwierdzony badaniami eksperymentalnymi. Metodologia procesu symulacji została przedstawiona w artykule.

Słowa kluczowe: nagniatanie, chropowatość powierzchni, symulacja MES

\section{INTRODUCTION}

Ball burnishing is a plastic deformation process, which can be used to improve surface characteristics and physical-mechanical properties of manufactured parts. Ball burnishing process improves the surface quality [1-5], increases the surface hardness of the workpiece [3-6], which in turn improves wear [7] and corrosion [8] resistances and inducing residual compressive stresses that improve the fatigue strength [6,9]. Ball burnishing is a cold working process, which takes place on the surface of pre-machined workpieces. The deforming element is a ball of diameter between 3 and $12 \mathrm{~mm}$ [10], which applies a normal force high enough to produce a small plastic deformation that displaces material of the peaks to the valleys of the micro-irregularities in the surface. The ball must be of a harder material than the workpiece, to achieve the compression of the surface, which allows to obtain a microcompressed layer of material $(2-10 \mu \mathrm{m})$ [11]. Thus, ball burnishing gives many advantages in comparison with other finishing process, such as hand polishing, grinding or shot peening [3]. In the past, most studies concerning to the ball burnishing process were focused on experimental tests [2-5,11-15], determining specific parameters such as the roughness before and after the burnishing process. In recent years, some researchers developed 2D and 3D models using the Finite Element Method (FEM) [1,3,6,16-19] to predict, study and analyze the influence of parameters of the burnishing ball process, allowing to reduce the high costs of experimental tests. The study of models has been focused on the prediction of compressive residual stress and the prediction of roughness simulating the burnishing process has been little studied. Some studies did not consider the roughness profile in the finite element model [16-18], some other considered it as a profile of semicircular [3,6] or triangular [19] patterns, both with similar characteristics corresponding to the machining process prior to burnishing; another study used linear interpolation of the measured data points to obtain a 2D profile of roughness [2]. Different manufacturing processes generate surface irregularities with diverse amplitudes and patterns, so to predict the surface finish by FEM, the modelation of these irregularities must be investigated. In this work a finite element model of ball burnishing process with random roughness was developed, which was used to predict residual stress and the roughness after burnishing. This model was validated by using experimental results carried out on cylindrical specimens of AISI 1045 steel, usually used in automotive industry. The roughness in the surface of the workpiece was generated by using a computational routine based on ANSYS ${ }^{\circledR}$ Parametric Design Language (APDL) developed by Aguilera et al. [20] to generate three-dimensional random roughness in cylindrical bars. Results show that the model developed is useful for predicting the residual stress and surface roughness after burnishing. The use of these models allows to reduce partial or totally the high cost of experimental testing. 


\section{EXPERIMENTAL STUDY OF BALL BURNISHING}

AISI 1045 steel was used as a workpiece material, this steel was selected due it is widely used in automotive industry. Tests were carried out in a TRENS ${ }^{\circledR}$ SN 32 turning center. Figure 2.1a shows the geometry of the test specimen, which was divided into two regions to evaluate the parameters of roughness before and after ball burnishing process. The cylindrical specimen was initially turned by using a tungsten carbide insert. Turning parameters were the turning speed $\left(101.8 \mathrm{~m} \cdot \mathrm{min}^{-1}\right)$ and the turning feed $\left(0.1 \mathrm{~mm} \cdot \mathrm{rev}^{-1}\right)$. First region of the specimen was burnishing by using a Diamond Burnishing Tool EDP\# S2300-00 (3/4" Shank) produced by ELLIOTT ${ }^{\circledR}$ Tool Technologies. The burnishing tool has a metal stem with a natural diamond semicircular chip in the end of it, with a $12.7 \mathrm{~mm}$ diameter. Second region only was turned (Fig. 2.1b).

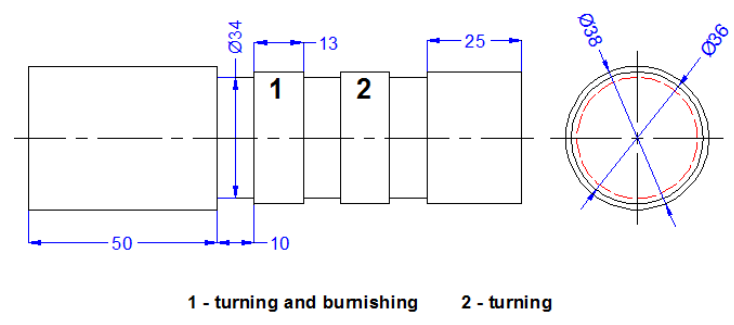

(a)

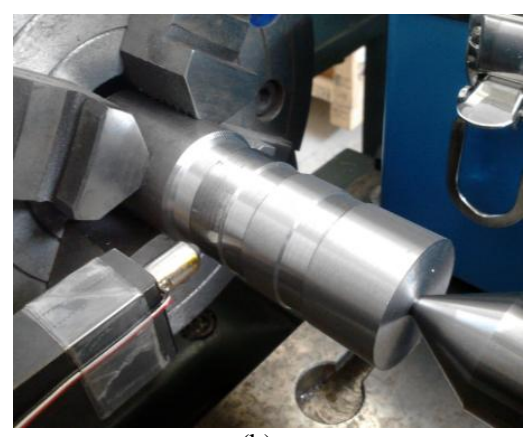

(b)

Figure 2.1. Cylindrical specimen, (a) orthogonal views of geometry, (b) in turning center

The process variables for ball burnishing were burnishing force $(294 \mathrm{~N})$, burnishing speed $\left(71 \mathrm{~m} \cdot \mathrm{min}^{-1}\right)$ and burnishing feed $\left(0.2 \mathrm{~mm} \cdot \mathrm{rev}^{-1}\right)$, which represents the parameters with greater percentage importance of the ball burnishing according the literature (Fig. 2.2a) [21]. The values of these parameters were selected according to the range of values presented by different studies (Fig. 2.2b, c and d) and the features of the turning center. Two types of ball burnishing apparatus are used in industry with mechanical springs [35] or hydrostatic springs [22]. The burnishing tool that was used in this work it is the first type, therefore to apply the burnishing force in the turning center was necessary to obtain the rate static burnishing force - depth of burnishing. 


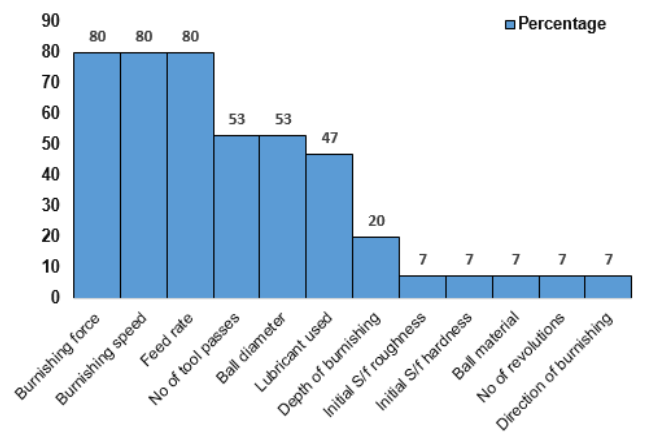

(a)

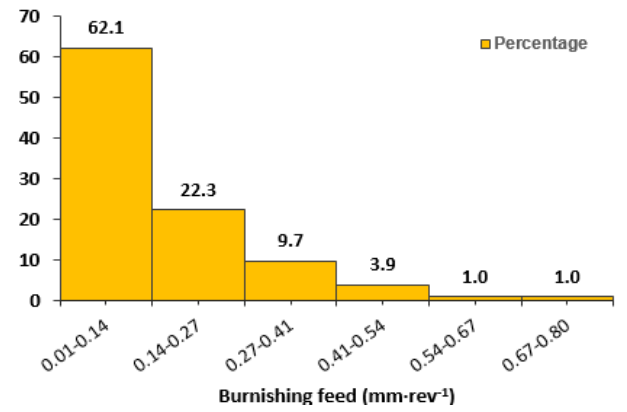

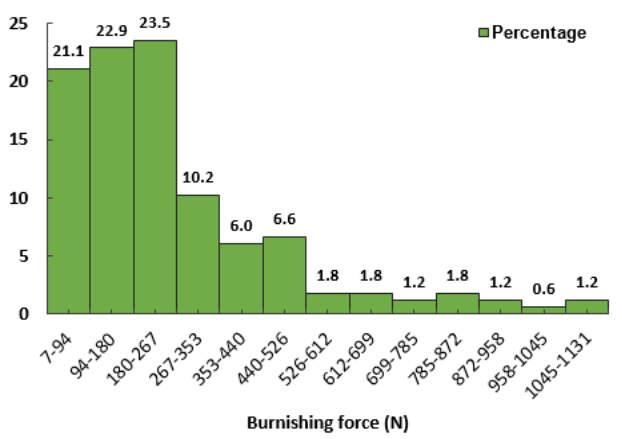

(b)

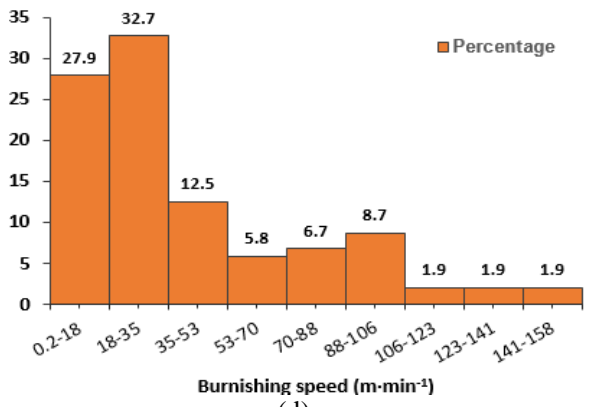

(d)

Figure 2.2. Percentage importance of the ball burnishing parameters according the literature: (a) process variables [21]; (b) burnishing force; (c) burnishing feed; (d) burnishing speed

The static burnishing force was obtained by compression of the ball burnishing on the stem of a digital dynamometer model AFG-2500N (Fig. 2.3a). Additionally, a strain gauge type EA06-250BG-120 produced by VISHAY ${ }^{\circledR}$ was implemented in the metal stem of the burnisher to obtain the microstrains, which was recorded by using a VISHAY ${ }^{\circledR}$ Strain Indicator Model $\mathrm{P} 3$. Figure $2.3 \mathrm{~b}$ shows the rate between the static burnishing force and microstrains; an average of three measurements of microstrain for each static burnishing force was recorded in a range of 0 to $294 \mathrm{~N}$. Depth of burnishing was obtained by compression of the ball burnishing on the workpiece, in this test the relationship of the depth of burnishing (displacement of the auxiliary carriage turning center) and microstrain was recorded (Fig. 2.3c); less measurements were recorded due to the accuracy of the auxiliary carriage turning center. Finally, it was possible to correlate the burnishing force and depth of burnishing through the microstrains (Fig. 2.3d); this information was useful for the experimental test and development the finite element model of ball burnishing process.

Once made the experimental test, the typical roughness parameters, hardness and residual stress were measured, before (turning) and after burnishing. The equipment used for measure each variable was:

Roughness: three of the typical roughness parameters: $R_{a}$ (arithmetical mean roughness), $R_{z}$ (ten-point mean roughness), and $R_{t}$ (maximum height); which are the most representative parameters that describes the surface roughness were recorded. These parameters are defined 
in ISO 4287 and were measured in the same advancing direction of turning and burnishing processes (with an evaluation length of $0.8 \mathrm{~mm}$ [23]) using a Mitutoyo ${ }^{\circledR}$ Suftest-211 profilometer. Three measurements of each roughness parameter were carried out.

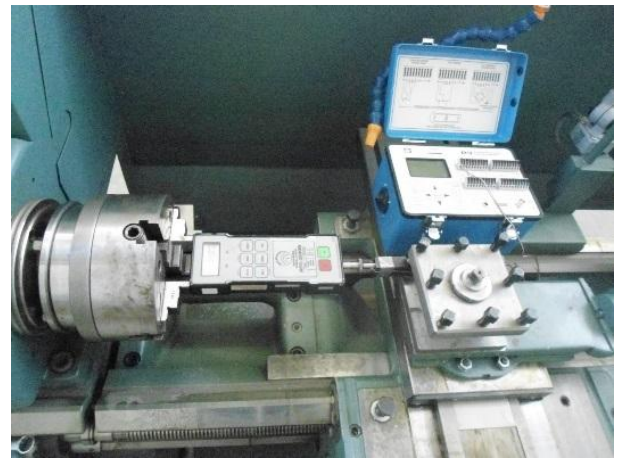

(a)

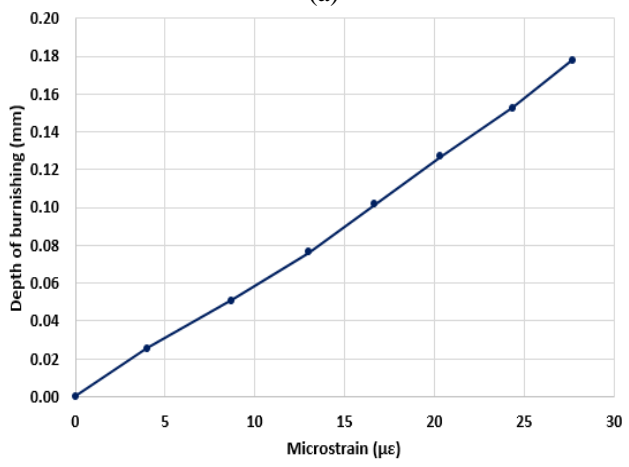

(c)

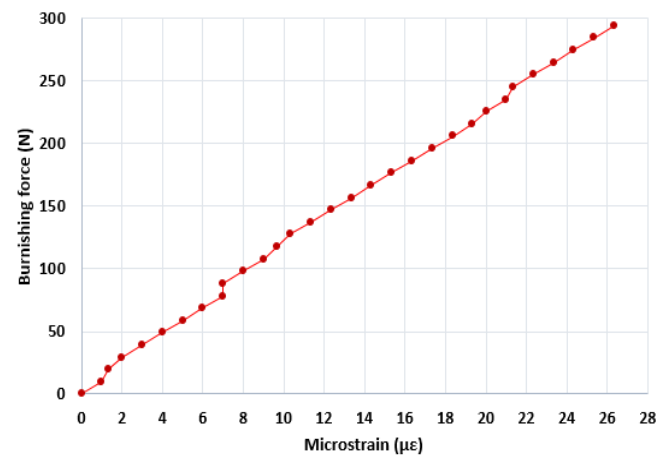

(b)

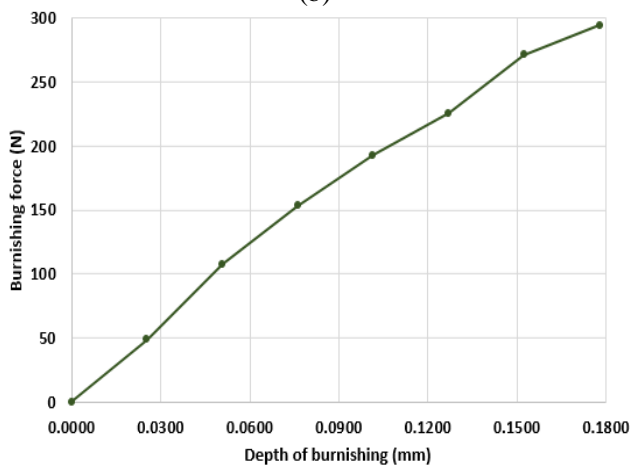

(d)

Figure 2.3. (a) Static burnishing force test, (b) static burnishing force - microstrain,

(c) depth of burnishing - microstrain, (d) burnishing force - depth of burnishing

Hardness: three measurements of Brinell hardness (HBN) were recorded in different points of the workpiece by using a portable hardness tester HARDMATIC ${ }^{\circledR}$ HH-411.

Residual stress: the relationship of the principal residual stresses at different depths form the surface were measured using a residual stress measurement Prism ${ }^{\circledR}$ (Fig. 2.4a and b) produced by stresstech group. Prism ${ }^{\circledR}$ residual stress is based on Hole-Drilling and Electronic Speckle Pattern Interferometry (ESPI) techniques. The technology of Prism ${ }^{\circledR}$ utilizes stressrelaxation technique, where a small hole is drilled into the material thus relaxing the stress along the hole boundaries. The resulting surface distortion can then be measured precisely using ESPI system [24]. Figures 2.4c and d show the surface after turning and burnishing, respectively. In the Figure $2.4 \mathrm{~d}$ can be observed the plastic deformation and flattened peaks and therefore the decrease of the roughness.

Table 2.1 shows the experimental measurements of $R_{a}^{\prime}, R_{z}^{\prime}$ and $R_{t}^{\prime}$ before burnishing (turning); $R_{a}, R_{z}$ and $R_{t}$ after burnishing; the index of the roughness change $\left(K R_{a}\right)$ and the Brinell hardness $(\mathrm{HBN})$. The index of the roughness change which can be determined using 
the expression (1). Where $R_{a}^{\prime}$ is the average roughness before burnishing and $R a$ later.

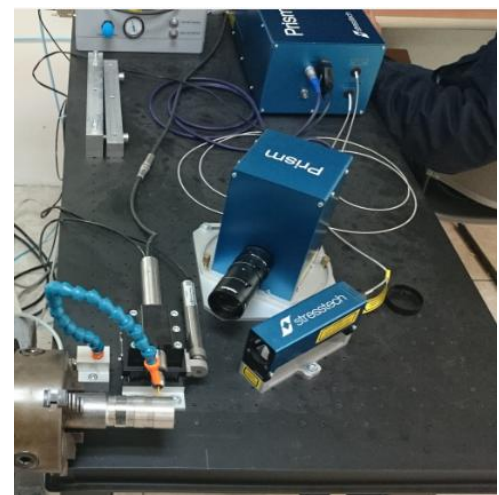

(a)

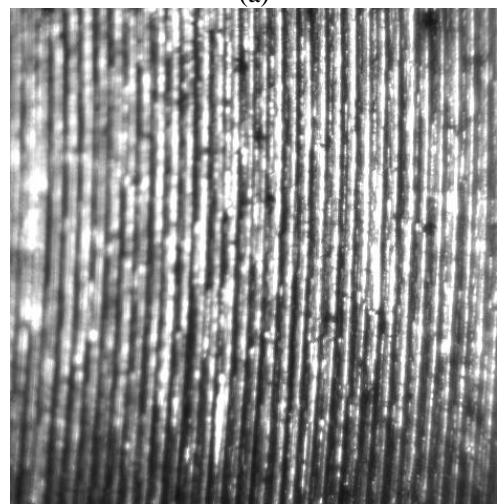

(c)

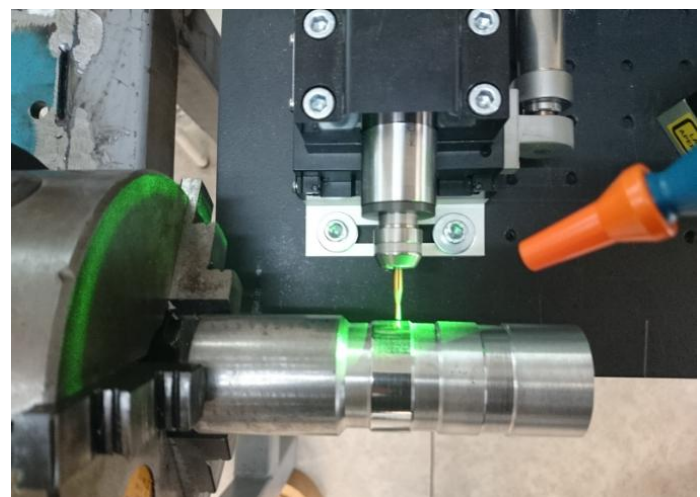

(b)

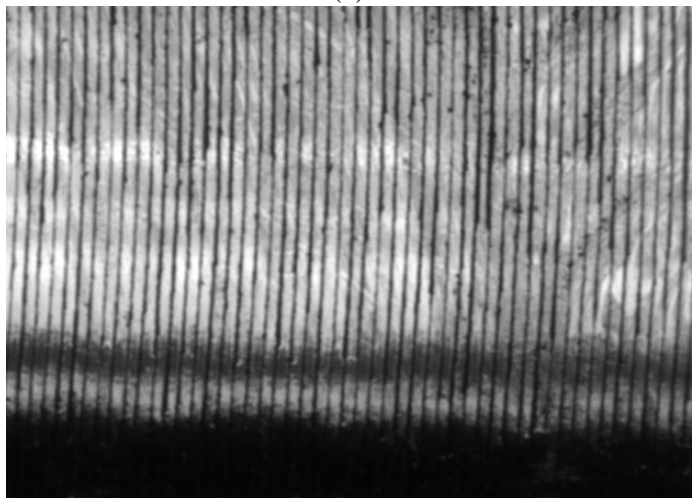

(d)

Figure 2.4. (a) Prism ${ }^{\circledR}$ equipment, (b) Measuring the residual stress in the cylindrical specimen, (c) surface after turning (10x), (d) surface after burnishing (10x)

$$
K_{R a}=\frac{R^{\prime} \mathrm{a}}{R a}
$$

Table 2.1. Experimental results of roughness parameters, index of the roughness change and Brinell hardness

\begin{tabular}{cccccccccc}
\hline Measurement & \multicolumn{4}{c}{ Parameters after turning $(\mu \mathrm{m})$} & \multicolumn{3}{c}{ Parameters after burnishing $(\mu \mathrm{m})$} & \multirow{2}{*}{$K R_{a}$} \\
\cline { 2 - 10 } No. & $R_{a}^{\prime}$ & $R_{z}^{\prime}$ & $R_{t}^{\prime}$ & $H B N$ & $R_{a}$ & $R_{z}$ & $R_{t}$ & $H B N$ & \\
\hline 1 & 4.96 & 26.6 & 36.5 & 208 & 1.37 & 10.3 & 14.7 & 234 & 3.62 \\
2 & 4.59 & 26.5 & 34.1 & 208 & 1.28 & 9.0 & 12.8 & 229 & 3.58 \\
3 & 4.53 & 24.6 & 31.1 & 202 & 1.17 & 8.6 & 11.9 & 226 & 3.87 \\
\hline
\end{tabular}

Expressions (2), (3) and (4) are commonly employed by profilometers to determine the values of $R_{a}, R_{z}$, and $R_{t}$, respectively, in an evaluated length $l$. Where $n$ is the number of evaluations; $y_{i}$ is the peak height or valley depth at a point $i, y_{v i}$ is the valley depth at a point $i$; $y_{c i}$ is the peak height at a point $i ; y_{\text {vimin }}$, is the lowest valley depth of all measurements and $y_{\text {cimax }}$, is the highest peak of all measurements. 


$$
\begin{gathered}
R a=\frac{1}{n} \sum_{i=1}^{n}\left|y_{i}\right| \\
R z=\frac{\sum_{i=1}^{5 n}\left|y_{c i}\right|+\sum_{i=1}^{5 n}\left|y_{v i}\right|}{5} \\
R t=y_{\text {cimax }_{\text {max }}}+y_{v_{\text {min }}}
\end{gathered}
$$

\section{SIMULATION OF BALL-BURNISHING PROCESS WITH ROUGHNESS}

To simulate three-dimensional rough surface in a cylindrical specimen of AISI 1045 steel, a computational routine was used. The routine to simulate surface roughness in rectangular and cylindrical specimens (Fig. 3.1) was developed and validated by Aguilera et al. [20] and enables probabilistic modeling of roughness by a normal distribution, which most often is present in many phenomena that occur in nature, industry and research [25]. To generate a three-dimensional roughness regardless ripple and lay, the routine requires the mean $(\bar{x})$ and standard deviation $(s)$ of a normal distribution of actual roughness. Additionally, the macro requests the value of peak (nodal) density and dimensions of the specimen, the procedure executed by the macro to generate a specimen with superficial roughness can be shown in the reference [20].

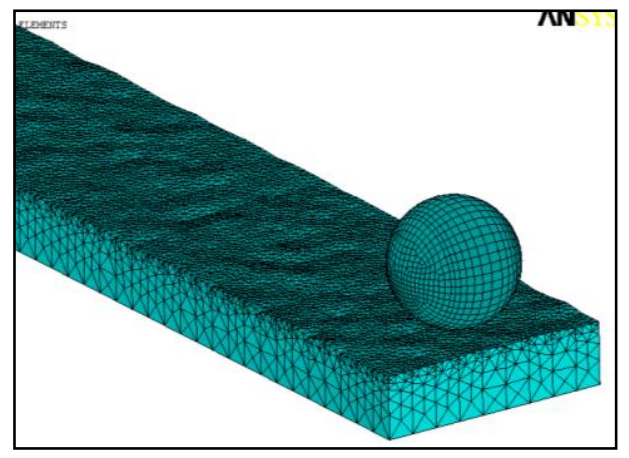

(a)

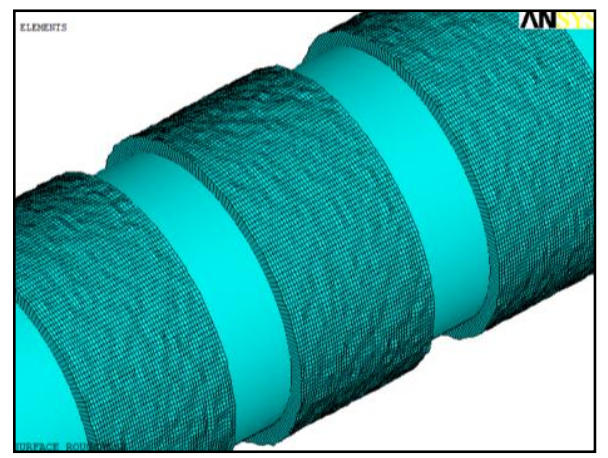

(b)

Figure 3.1. Geometric model of random roughness in specimen, (a) rectangular, (b) cylindrical [20]

The results found by Aguilera et al. [20] show that with a nodal density above 2560 that the mean presents an error no greater than $1 \%$, and less than $2 \%$ for standard deviation comparing numerical with experimental results, which are acceptable values. Errors can be reduced by increasing the nodal density, however it must be remembered that a model with a too dense mesh will affect the computational time of the simulation with not significant contribution in reducing the error.

Nowadays, there have been developed different finite element models of the ball burnishing process. Table 3.1 shows some characteristics of them. In most cases, the process carried out on cylindrical specimens, the ball is considered as a rigid body or a material of high rigidity 
and residual stresses were measured by the X-ray diffraction techniques.

Table 3.1. Summary of some finite element model of ball burnishing process

\begin{tabular}{|c|c|c|c|c|c|c|}
\hline Reference & Model & Software & Material Model & $\begin{array}{c}\text { Ball } \\
\text { diameter } \\
(\mathrm{mm})\end{array}$ & Work Material & $\begin{array}{l}\text { Measured } \\
\text { Variable }\end{array}$ \\
\hline$[6]$ & $\begin{array}{l}2 \mathrm{D} \\
3 \mathrm{D}\end{array}$ & $\begin{array}{l}\text { DEFORM-2D } \\
\text { DEFORM-3D }\end{array}$ & Elastoplastic & 6 & AISI 52100 & $\begin{array}{l}\text { Surface roughness } \\
\text { and residual stress }\end{array}$ \\
\hline$[26]$ & $2 \mathrm{D}$ & Zébulon & Elastoplastic & $\begin{array}{c}6,9,12 \\
15,20\end{array}$ & AISI 1042 & $\begin{array}{l}\text { Surface roughness, residual stress } \\
\text { and the influence of burnishing } \\
\text { parameters (penetration depth, feed } \\
\text { rates, diameter of the ball and } \\
\text { initial surface quality) on surface } \\
\text { roughness and the residual stress } \\
\text { distribution }\end{array}$ \\
\hline [16] & $\begin{array}{l}2 \mathrm{D} \\
3 \mathrm{D}\end{array}$ & ABAQUS & Elastic-plastic & 4,6 & Ti6Al7Nb alloy & $\begin{array}{c}\text { Residual stress and } \\
\text { strain distribution }\end{array}$ \\
\hline [19] & $2 \mathrm{D}$ & ABAQUS & Elastic-plastic & 3.2 & $11 \mathrm{SMn} 30$ Steel & $\begin{array}{l}\text { Surface roughness, residual stress, } \\
\text { and the influence of burnishing } \\
\text { parameters (feed rates and } \\
\text { penetration depth) on surface } \\
\text { roughness and residual stress. } \\
\text { The effect of the burnishing } \\
\text { process on the material }\end{array}$ \\
\hline [3] & $2 \mathrm{D}$ & ANSYS $^{(}$ & $\begin{array}{l}\text { Isotropic, Plastic } \\
\text { Hardening }\end{array}$ & 6 & AISI 1045 & Residual stress \\
\hline [27] & $3 \mathrm{D}$ & Zébulon & $\begin{array}{l}\text { Elastoplastic and } \\
\text { elastic }\end{array}$ & 9 & AISI 1042 & $\begin{array}{l}\text { Residual stress and } \\
\text { material displacement }\end{array}$ \\
\hline [7] & $3 \mathrm{D}$ & ABAQUS/Implicit & $\begin{array}{l}\text { Non-linear combined } \\
\text { isotropic/kinematic } \\
\text { strain hardening law }\end{array}$ & 6 & $\begin{array}{c}\text { IN718 } \\
\text { Ti-6Al-4V } \\
\text { Titanium alloy }\end{array}$ & Residual stress \\
\hline [18] & $3 \mathrm{D}$ & ABAQUS/Explict & Elastoplastic & 12.7 & SE508 Nitinol & $\begin{array}{l}\text { Contact stresses, residual } \\
\text { stresses, and strain profiles }\end{array}$ \\
\hline
\end{tabular}

In this work, a 3D finite element model of the burnishing process was modeled with a nodal density of 2560 in a cylindrical area of $339.3 \mathrm{~mm}^{2}$ ( $3 \mathrm{~mm}$ long and $18 \mathrm{~mm}$ radius). The computational routine generates a three-dimensional rough surface by extrusion the area generated. Other geometric characteristics of developed FE model are shown in Figure 2.1a. To generate the nodes in the surface of workpiece the mean and standard deviation were $4.69 \mu \mathrm{m}$ and $16.95 \mu \mathrm{m}$, respectively; the mean value was the average of the three measurements of $R_{a}$ obtained experimentally and the standard deviation was obtained from the average of measurements of $R_{t} / 2$.

Finite element model shows in the Figure 3.2, which was meshed with 28.992 elements. The element SOLID164 was used; this element is defined by eight nodes with 9 degrees of freedom at each node: translations, velocities, and accelerations in the nodal $\mathrm{x}, \mathrm{y}$, and $\mathrm{z}$ directions. A bilinear isotropic material with the mechanical properties of AISI 1045 steel was used. The mechanical properties were: Elastic modulus E $=200 \mathrm{GPa}$, Poisson's ratio $v=0.3$, Yield strength $\sigma_{\mathrm{y}}=340 \mathrm{MPa}$ and Tang. Mod. $=2.133$ [3].

To reduce computational time, the parts which would not have deformation were modeled as rigid bodies; these parts are shown in Figure 3.2, the extremes (red) and the ball (purple); considering the ball as rigid body as is used for other authors $[6,16]$. The cylinder was modeled hollow because the stresses are neglected in the center [28] due the residual stress is produced approximately $1 \mathrm{~mm}$ depth or less below surface $[3,6,16]$. Besides these considerations, only on the zone to be burnished was added roughness (Figure 3.2b).

For boundaries, the translational movement was totally avoided in the cylinder and only the rotation in Z-axis is allowed. For the ball, only movement in Y-axis is used. 


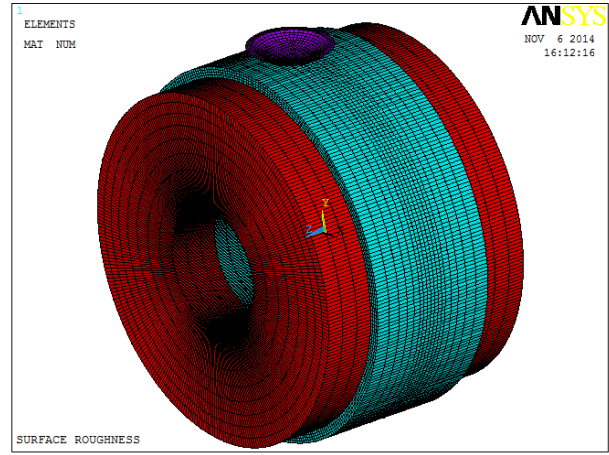

(a)

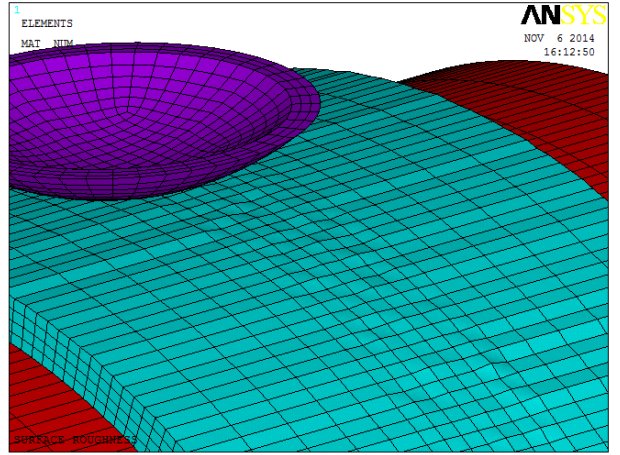

(b)

Figure 3.2. (a) Finite element model of ball burnishing process,

(b) roughness added only on the zone to be burnished

For loads, a rotational movement is applied on the extremes to produce a rotational speed of $630 \mathrm{rpm}$; this rotational movement is stopped $1.0 \mathrm{~s}$ before simulation ends to avoid stresses due inertia. The ball applies a constant force of $294 \mathrm{~N}$ while a transversal movement along $3 \mathrm{~mm}$ is also generated. When the ball finishes the burnishing process, is retracted to avoid stresses due pressure. A CPU with 48 cores and 256 GB in RAM was used to solve the model; with this computer the computational time was $60.5 \mathrm{~h}$.

Once simulated the ball burnishing process, the new surface roughness was analyzed by measuring the change of nodal displacement in the radial direction; the new roughness $\left(R_{a}\right)$ is determined by equation (2). In addition, the new roughness after burnishing and the numerical residual stresses were validated with experimental data.

\section{RESULTS AND DISCUSSION}

Experimental results shown that the roughness parameters: $R_{a}, R_{z}$ and $R_{t}$ after ball burnishing process decreases in $73 \%, 64 \%$ and $61 \%$, respectively. These percentages of improvement in the surface quality are considered satisfactory compared with those reported in the literature (Table 4.1). The hardness increase of the surface layer was $10 \%$ (Brinell scale); while Hamadache et al. (2006) [5] found an improvement in hardness of 10.25\%, El-Tayeb et al. (2007) [32] between 20-30\% and Rodríguez et al. (2012) [3] of $60 \%$.The index of the roughness change was 3.69. Ball burnishing provides good surface finish, induce compressive residual stresses and therefore increase the hardness in the surface layer.

Figure 4.1 shows the principal residual stresses $\sigma 1$ and $\sigma 2$ in different depths below the surface of the workpiece, in both Figures can be observed a similar behavior comparing numerical with experimental results. The maximum compressive stress was presented in $\sigma 1$ around $370 \mathrm{MPa}$ at a depth near to $0.4 \mathrm{~mm}$. The maximum depth at which the compressive residual stresses are presented at $0.7 \mathrm{~mm}$. In prior works about of the ball burnishing process found that the compressive residual stresses are a range between 0.4 to $2 \mathrm{~mm}[1,3,6,6,26,27]$. At the depth of $0.54 \mathrm{~mm}$ for both experimental residual stresses curves, it can be observed an atypical value of residual stress, probably this value is due to an imperfection of the workpiece in that point. 


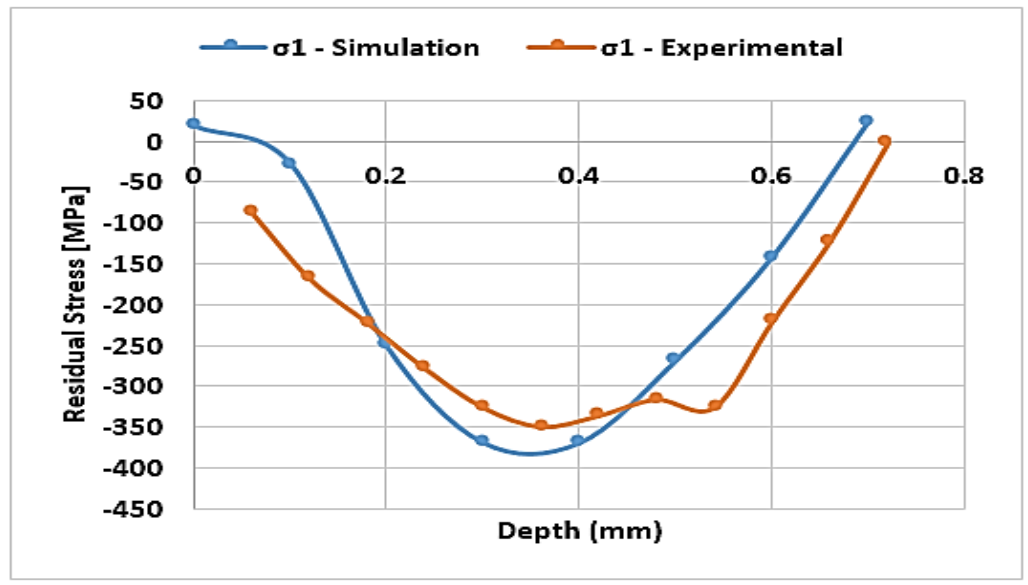

(a)

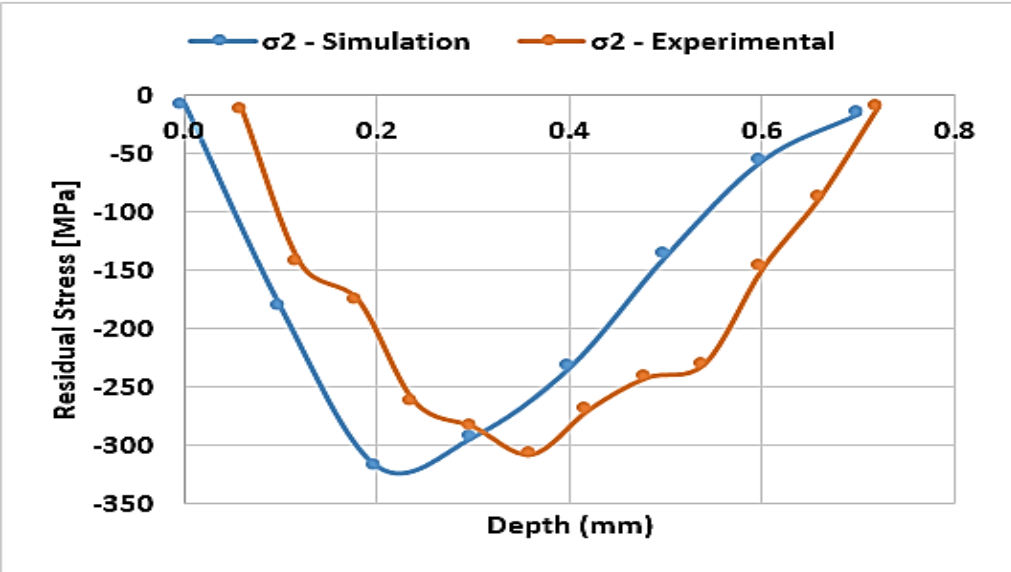

(b)

Figure 4.1. Residual stresses; (a) $\sigma 1$; (b) $\sigma 2$

Table 4.1. Summary of improvement in the surface quality in some studies

\begin{tabular}{cc}
\hline Reference & Improvement in the surface quality $(\%)$ \\
\hline$[1]$ & $83\left(R_{a}\right)$ and $77\left(R_{t}\right)$ \\
{$[3]$} & 90 \\
{$[5]$} & 70 \\
{$[6]$} & 91 \\
{$[26]$} & $75\left(R_{a}\right)$ and $59\left(R_{t}\right)$ \\
{$[29]$} & 70 \\
{$[30]$} & 84 \\
{$[31]$} & $85-95$ \\
{$[32]$} & 40 \\
{$[33]$} & 87 \\
{$[34]$} & $60-80$ \\
\hline
\end{tabular}


Final roughness $\left(R_{a}\right)$ obtained after burnishing simulation was 0.95 . To obtain this value, from the develop model was gotten the radial displacement of nodes on the area where was applied the initial roughness, using equation (2). The value for experimental roughness after burnishing was 1.17 to 1.37 , therefore the obtain value from simulation is considered a good approximation.

\section{CONCLUSIONS}

In this paper, a 3D finite element model of the ball burnishing process with random roughness was developed, this model was used to understand and predict successfully the roughness after burnishing, residual stress values and their depth. The results were obtained using the bilinear isotropic material. From the experimental results, it can be observed that reduction in the arithmetical mean roughness $\left(R_{a}\right)$ was $73 \%$ and increase the hardness of the surface layer by $10 \%$ (Brinell scale). Residual stresses measurements based on Hole-Drilling and Electronic Speckle Pattern Interferometry (ESPI) techniques and the FEM show that compressive stresses are introduced in the workpiece; these residual stresses are presented about $0.7 \mathrm{~mm}$ in depth and present a similar behavior and depth comparing with the numerical results. Numerical roughness $R_{a}$ presented a good approximation with the experimental result considering the simplifications of the model. In a future, the computational routine to generate three-dimensional roughness by a normal distribution and the methodology to develop a 3D ball burnishing model in a finite element software can be used to predict the surface finish and the compressive residual stresses after burnishing process allows to reduce partial or totally the high cost of experimental testing.

\section{ACKNOWLEDGMENTS}

The authors acknowledge the Division of Engineering of the Irapuato-Salamanca Campus of the University of Guanajuato for the valuable contribution of equipment and material for the realization of this work, we also thank the Office of Research Support and Postgraduate (DAIP) of the University of Guanajuato for it is economic support for the acquisition of burnishing tool. The author Saldaña R. A. acknowledge the financial support of National Council for Science and Technology (CONACYT) for his doctoral studies.

\section{LITERATURE}

[1] BOUGHARRIOU A., SAÏ K., BOUZID W.: Finite element modeling of burnishing process, Materials Technology: Advanced Performance Materials, 2010a, 25(1), 56-67.

[2] HASSAN A. M., MAQABLEH A. M.: The effects of initial burnishing parameters on non-ferrous components, Journal of Materials Processing Technology, 2000, 102(1), 115-121.

[3] RODRÍGUEZ A., LÓPEZ DE LACALlE L. N., CELAYA A., LAMIKIZ A., ALBIZURI, J.: Surface improvement of shafts by the deep ball-burnishing technique. Surface and Coatings Technology, 2012, 206(11), 2817-2824.

[4] EL-TAYEB N. S. M., LOW K. O., BREVERN P. V.: Influence of roller burnishing contact width and burnishing orientation on surface quality and tribological behavior of Aluminum 6061, Journal of materials processing technology, 2007, 186(1), 272-278.

[5] HAMADACHE H., LAOUAR L., ZEGHIB N. E., CHAOUI K.: Characteristics of Rb40 steel superficial layer under ball and roller burnishing, Journal of Materials Processing Technology, 2006, 180(1), 130-136. 
[6] YEN Y. C., SARTKULVANICH P., ALTAN T.: Finite element modeling of roller burnishing process, CIRP Annals-Manufacturing Technology, 2005, 54(1), 237-240.

[7] KLOCKE F., BÄCKER V., WEGNER H., ZIMMERMANN M.: Finite element analysis of the roller burnishing process for fatigue resistance increase of engine components, Proceedings of the Institution of Mechanical Engineers, Part B: Journal of Engineering Manufacture, 2011, 225(1), 2-11.

[8] MAHMOOD H. A., AL-DHIFI S. Z.: Improvement in the wear resistance of brass components by the ball burnishing process. Journal of Materials Processing Technology, 1999, 96(1), 73-80.

[9] DÍAZ R. S., ROBERT N. T., BOADA C. O.: Los tratamientos mecánicos superficiales para el acabado de las piezas. Una aproximación a una manufactura diferente, Quinta Conferencia Internacional de Ingeniería Mecánica. Santa Clara, Cuba, 2008.

[10] TRAVIESO J. A., GONZÁLEZ H. A., DOMÍNGUEZ A.: Estudio del proceso de bruñido con bola para la mejora de acabado superficial en superficies convexas, XVIII Congreso Nacional de Ingeniería Mecánica CNIM 2010, 2007, Vol. 186, p. 167.

[11] TRAVIESO R. J. A., DESSEIN G., GONZÁLEZ R. H. A.: Improving the surface finish of concave and convex surfaces using a ball burnishing process, Materials and Manufacturing Processes, 2011, 26(12), 1494-1502.

[12] RODRÍGUEZ A., LACALlE L. L. D., CELAYA A., FERNÁNDEZ A., LAMIKIZ A.: Ball burnishing application for finishing sculptured surfaces in multi-axis machines, International Journal of Mechatronics and Manufacturing Systems, 2011, 4(3), 220-237.

[13] RAJASEKARIAH R., VAIDYANATHAN S.: Increasing the wear-resistance of steel components by ball burnishing, Wear, 1975, 34(2), 183-188.

[14] SHIOU F. J., CHEN C. H.: Freeform surface finish of plastic injection mold by using ball-burnishing process, Journal of Materials Processing Technology, 2003, 140(1), 248-254.

[15] LOH N. H., TAM S. C., MIYAZAWA S.: A study of the effects of ball-burnishing parameters on surface roughness using factorial design, Journal of Mechanical Working Technology, 1989, 18(1), 53-61.

[16] SAYAHI M., SGHAIER S., BELHADJSALAH H.: Finite element analysis of ball burnishing process: comparisons between numerical results and experiments, The International Journal of Advanced Manufacturing Technology, 2013, 67(5-8), 1665-1673.

[17] SAI W. B., SAÏ K.: Finite element modeling of burnishing of AISI 1042 steel, The International Journal of Advanced Manufacturing Technology, 2005, 25(5-6), 460-465.

[18] FU C. H., GUO Y. B., MCKINNEY J., WEI X. T.: Process mechanics of low plasticity burnishing of Nitinol alloy, Journal of materials engineering and performance, 2012, 21(12), 2607-2617.

[19] BALLAND P., TABOUROT L., DEGRE F., MOREAU V.: Mechanics of the burnishing process, Precision Engineering, 2013, 37(1), 129-134.

[20] AGUILERA G. E., PLASCENCIA M. H., LEDESMA O. E., SALDAÑA R. A., SALDAÑA R. N., NEGRETE R. G.: Three-dimensional modeling of surface roughness in machined bars of sintered steel, Conference proceedings Innovative Manufacturing Technology IMT 2013, Kraków, Poland, from 18th to $20^{\text {th }}$ November.

[21] MAHAJAN D., TAJANE R.: A Review on Ball Burnishing Process, International Journal of Scientific and Research Publications, 2013, 194.

[22] DE LACALLE L. L., LAMIKIZ A., SÁNCHEZ J. A., ARANA J. L.: The effect of ball burnishing on heattreated steel and Inconel 718 milled surfaces, The International Journal of Advanced Manufacturing Technology, 2007, 32(9-10), 958-968.

[23] ISO 4287:1997.: Geometrical Product Specifications (GPS) Surface Texture: Profile Method Terms. Definitions and Surface Texture Parameters, International Organisation for Standardisation, 1997.

[24] http://www.stresstechgroup.com/

[25] WALPOLE R. E., MYERS R. H., MYERS S. L., YE K.: Probability and statistics for engineers and scientists, 9th Edition, Pearson, 2011.

[26] BOUGHARRIOU A., SAÏ W. B., SAÏ, K.: Prediction of surface characteristics obtained by burnishing, The International Journal of Advanced Manufacturing Technology, 2010b, 51(1-4), 205-215.

[27] BOUZID W. S., SAÏ, K.: Finite element modeling of burnishing of AISI 1042 steel, The International Journal of Advanced Manufacturing Technology, 2005, 25(5-6), 460-465.

[28] SAldaña R. A., AGUilera G. E., Plascencia M. H., LEDESMA O. E., AlCANTAR C. V. A.: Análisis teórico-numérico de esfuerzos generados para bruñido de bola sobre cilindros rotativos, XX Congreso Internacional Anual de la SOMIM, Juriquilla, Querétaro, México, 24 al 26 de Septiembre.

[29] ROETTGER K.: Walzen hartgedrehter Oberflaechen, PhD Dissertation, WZL, RWTH Aachen, 2002.

[30] PRASAD K., KRISHNA R., JANARDHAN G., RAJU A., NAHAVANDI S.: Experimental investigation and finite element analysis for the study of residual stresses in roller burnished components. International journal of applied engineering research, 2006, 1(3), 427-436. 
[31] LÓPEZ DE LACALLE L. N., LAMIKIZ A., MUÑOA J., SÁNCHEZ J. A.: Quality improvement of ball-end milled sculptured surfaces by ball burnishing, International Journal of Machine Tools and Manufacture, 2005, 45(15), 1659-1668.

[32] EL-TAYEB N. S. M., LOW K. O., BREVERN P. V.: Influence of roller burnishing contact width and burnishing orientation on surface quality and tribological behavior of Aluminum 6061, Journal of Materials Processing Technology, 2007, 186(1), 272-278.

[33] DE LACALLE L. L., LAMIKIZ A., SÁNCHEZ J. A., \& ARANA J. L.: The effect of ball burnishing on heattreated steel and Inconel 718 milled surfaces. The International Journal of Advanced Manufacturing Technology, 2007, 32(9-10), 958-968.

[34] TRAVIESO R. J. A., SÁNCHEZ E. A. J., NÁPOLES A. A., HUERTAS T. J. L., GÓMEZ G. D., GONZÁLEZ R. H. A.: Comparativa del proceso de bruñido con bola en máquinas de 3 y 5 ejes en piezas de aluminio A92017 y A 96351, XIX Congreso Nacional de Ingeniería Mecánica, 2012.

[35] BROSTOW W., CZECHOWSKI K., RUSEK P., TOBOŁA D., WRONSKA I.: Tribology of tool steels: efects of burnishing and nitriding, Conference proceedings of International Conference on Innovative Manufacturing Technology, 2013, Kraków, Poland, from 18th to $20^{\text {th }}$ November. 